\title{
Leadership Dichotomy: Women are more Efficacious in Working with Diverse People
}

\author{
Shweta Bhatt ${ }^{1}$, Dr. Nidhi Kesari ${ }^{2}$
}

\section{ABSTRACT}

It is evident since ages that gender discrimination is a common feature in all societies. Even in developed countries, the prejudices and obstacles that women have had to encounter and surmount seem almost identical. The peculiar stigma attached to women all over the world is based on religious bias. "Woman" is depicted as a temptress and is warned against in almost all religions of the world. Woman's basic stigma therefore originates in religion.

The Rig Veda says, "The wife and husband, being the equal halves of one substance, are equal in every respect; therefore, both should join and take equal parts in all works, religious and secular.” The Upanishads clearly declare that we individual souls are neither male nor female.

Rig Veda clearly proclaims that women should be given the lead in ruling the nation and in society, and that they should have the same right as sons over the father's property. "The entire world of noble people bows to the glory of the glorious woman so that she enlightens us with knowledge and foresight. She is the leader of society and provides knowledge to everyone. She is symbol of prosperity and daughter of brilliance. May we respect her so that she destroys the tendencies of evil and hatred from the society.

In ancient India, women occupied a very important position, in fact a superior position to, men. It is a culture whose only words for strength and power are feminine -"Shakti" means "power" and "strength." All male power comes from the feminine. Literary evidence suggests that kings and towns were destroyed because a single woman was wronged by the state. For example, Valmiki's Ramayana teaches us that Ravana and his entire clan were wiped out because he abducted Sita. Veda Vyasa's Mahabharatha teaches us that all the Kauravas were killed because they humiliated Draupadi in public. Elango Adigal's Sillapathigaram teaches us Madurai, the capital of the Pandyas was burnt because Pandyan Nedunchezhiyan mistakenly killed her husband on theft charges.

Keywords: Efficacious, Collegial Approach, Leadership Traits, Multi-Tasking, Entrepreneurial Competency.

\footnotetext{
${ }^{1}$ Research Scholar, Department of Business Administration, DDU Gorakhpur University, Gorakhpur, U.P , India.

${ }^{2}$ Assistant Professor, Shaheed Sukhdev College of Business Studies, University of Delhi, Delhi, India. (C) 2015 I S Bhatt, N Kesari; licensee IJIP. This is an Open Access Research distributed under the terms of the Creative Commons Attribution License (http://creativecommons.org/licenses/by/2.0), which permits unrestricted use, distribution, and reproduction in any Medium, provided the original work is properly cited.
} 
Lord Buddha was the first and foremost person who not only recognised the importance of women to the society but also made an effort to enhance the social status at par to the men in respect of spiritual development which opened the door for the full participation of women in the field of religion by making them eligible for admission to what was known as the Bhikkhuni Sanghai - the Order of Nuns - that truly opened a new avenue of culture and social service and other ample opportunities to women in public life.

Spiritual human life cycle was divided into four main targets out of which Archaize, chasing materialism and sense pleasures (Kama). Holy Epic Ramayana makes it clear that these two pursuits should never be at the cost of Dharma (righteousness). In withholding dharma, both Artha and Kama can be and must be sacrificed. The ultimate goal of life is Moksha (liberation) and it can be attained only by relinquishing Artha and Kama and by strictly following a life of Dharma.

In ancient India, women occupied a very important position, in fact a superior position to men. Poet rightly said that "Ek Nahi Do-Do Matrayen, Nar se Bhari Nari." That is why Women is worshiped as Shakti which means "power" and "strength". It is generally said that there is a women behind the success of each and every man. Literary evidence reveals every war was fought because of woman. For example, Valmiki's Ramayana teaches us that Ravana, the king of Lanka, and his entire clan was wiped out because of the abduction ofSita wife of Lord Rama. Ved Vyasa's Mahabharatha also tells us that Kauravas were killed because of the humiliation of Draupadi caused by Duryodhana. Draupadi is presented as having a very impressive brilliant and strong personality and is projected as the primary cause of the battle of Kurukshetra.

According to Hindu philosophy, the world is made up of four main "Yugas". These four yugas are the Satya Yuga, the Treta Yuga, the Dwapara Yuga and lastly, the Kali Yuga. Each of these four Yugas involves stages of change; of evolution; one in which not only the physical universe undergoes change, but the whole thought process and consciousness of mankind metamorphoses either for better or for worse, depending upon that particular Yuga. The entire cycle of a Yuga starts from its highest point, the Golden Age of enlightenment.

Each subsequent age is witness to a gradual decline of wisdom, knowledge, intellect, life span, physical and spiritual strength in humankind as a whole. This automatically also implies decline and destruction of dharma or righteousness as well as the status of women's in different yuga. 


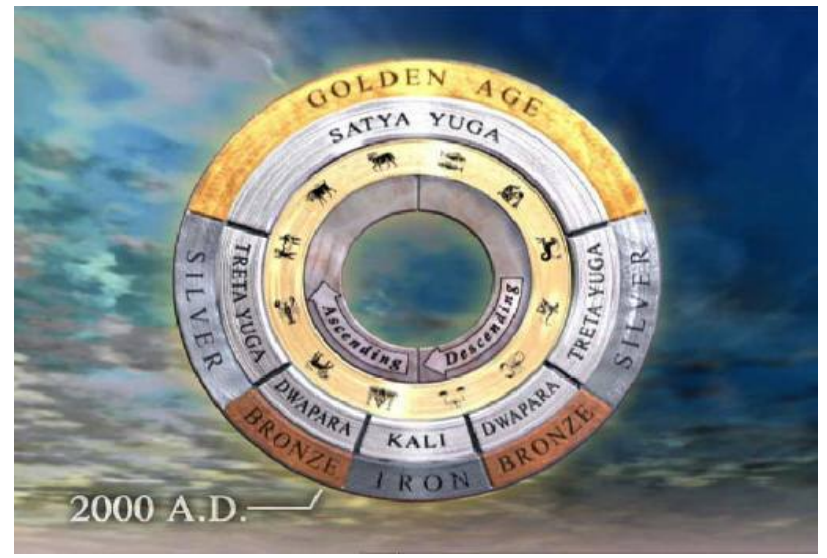

In Satya-Yuga, women occupied a key position in every matter. Every decision was taken after consulting woman. Right \& Wrong was always the point of discussion. Everyone was situated in the mode of goodness. The people of SatyaYuga are for the most part self-satisfied, merciful, friendly to all, peaceful, sober and tolerant.

The social status of women in TretaYuga, also occupied key position but they were not the part of decision-making. The holy book Ramayana tells us that the Sita was the role model of sacrifier, which is why she emerged as the final moral touchstone of the epic.

Mahatma Gandhi interpreted Sita as symbol to advocate the idea of women's strength, autonomy and ability to protect themselves having the spiritual power rather than depend on men for safety. His Sita was like a "lioness in spirit" before which Ravana became "as helpless as a goat." For the protection of her virtues even in Ravana's custody, she did not "need the assistance of Rama." Her own purity was her sole shield.

Gandhi wanted to create a whole army of new Sitas who were not brought up to think that a woman "was well only with her husband or on the funeral pyre." He wanted them to stop aspiring to be mere wives and instead become leaders of men, teaching them the message of peace and social harmony.

More than any other modern leader, he helped to create a favorable atmosphere for women's on large scale and respectful entry into public life. Gandhi's moral backing legitimized women's right to hold political office without having to wage long-drawn battles, like the Suffragists in the West had to do to. He portrayed Sita to break the shackles of domesticity, to come out of purdah, to lead political movements and teach the art of peace to this warring world.

The Dvapara Yuga is described as seeing the first drastic decline in righteousness of humanity. The dharma bull now only stands only on two legs, so the overall moral standard of the people in the Dvapara Yuga drops immensely. In this age, adherence to the Vedas becomes less acute.

People living in the Dvapara Yuga were zealous, valiant, courageous and competitive by nature. Further, they were cosmopolitan and pleasure-seeking, and so the divine intellect ceased to exist, and it was therefore seldom that anyone was wholly truthful. Because of this life of deceit, the living standard also decreased in the Dvapara Yuga. People were plagued by ailments, diseases and all sorts of desires. After suffering from these ailments, some people came to realize their misdeeds and performed penance. Along with charity, religious activity did not go much beyond 
this in the Dvapara Yuga. While some did attempt to organize sacrifices, they did so out of ostentation, mostly seeking material benefits rather than meaningful connection with the divine.

Despite these discouraging trends, the Dvapara Yuga was also characterized by some more positive elements. Science flourished during this time period, and people experienced the spiritual in terms of subtle energies and rational choices. Further, this age played host to the events described in the great Mahabharata epic, including the incarnation of the beloved deity Krishna (Vishnu's eighth avatar) and his subsequent participation in the battle between the righteous Pandavas and their corrupt counterparts the Kauravas. Bhagvad Gita is the single most popular set of teachings in Hinduism, wherein Krishna unravels the nature of the universe for the pensive Pandava warrior Arjuna. According to the Puranas this yuga ended at the moment when Krishna died and returned to his eternal abode of Vaikuntha.

By nature Men and women are generally differ in their physical and cognitive abilities, social skills and leadership styles. Women are said to be physically weaker and emotionally stronger than men. Women tend to focus on setting high standards of performance and the attainment of results. Women are far more apt to organize and work in a structured way in multi-tasking situations. Women are inherently good. They're morally superior and don't hurt people. There've been women political leaders throughout history.

Likewise the same chemical property of women are different yuga that has been transcended to this kali yuga also, where just like Sita \& Draupadi there are several examples of firm and determined women in the Kali Yuga who with their efficacious ability of leadership quality have been able to establish a great example in the history.

Margaret Thatcher the Iron Lady ( $20^{\text {th }}$ century): launched the Falklands war; contributed to the Cold War build-up of nuclear weapons in Europe; bombed Libya; supported foreign dictators like Augusto Pinochet; privatized many British social services and national industries.

Indira Gandhi (20 ${ }^{\text {th }}$ Century): led India in war against Pakistan; waged an internal campaign against Sikh communities in India; imprisoned political foes and censored the press; tested nuclear weapons.

I want to see more women compete for the highest positions in their countries ... we have to break down these attitudes that pigeon-hole and stereotype people, like, what does a leader look like... well a leader looks like somebody who's a man. - Hillary Clinton, 1/29/2013

Entering the organizations was once a formidable challenge for the women. Moving from infrastructural roles of the sixties and rising to managerial roles and responsibilities which is almost a Herculean task, and rising into senior management position is an uphill struggle. For women to occupy the position of CEO's in the past scenario, which was a rarity and almost impossibility, today is a reality. The striking part of women managers is that they are very good at juggling around the tasks. One of the strongest skills is their ability is at multi-tasking. Also women managers bring with them a different style and different skills. Researchalso confirms 
that women managers see things laterally, intuitively and differently. They can handle more contradictions, can tolerate more and deliver much more than men.

For women managers it is truly a case of twice the work and half the reward. It is a trying process for women to prove one again and again. However, women do feel that it is unfair to brand them as 'women manager' or to compare them with their male counterparts. Women have journeyed a long distance to enter the corporate boardrooms, take the leadership roles in organization and institutions and work as managers and employees across the levels of hierarchies in the organization.

A study was conducted in 2008 by the US based Pew Research Centre, found that public perceptions of women leaders was much more favorable to that of men in key leadership traits. The study also reveals that women were more compassionate, honest, and creative than men. In policy matters they were "widely judged to be better than men at dealing with social issues such as health care and education" and in job performance skills women received higher marks when measured for "standing up for one's principles in the face of political pressure; being able to work out compromises; keeping government honest; and representing the interests of 'people like you'

The study concluded that out of eight leadership traits, women get superiority in five i.e.; intelligence, honesty, outgoingness, compassion, and creativity whereas men and women were judged equal in respect of work ethic and ambition but there were one trait in which men came on the top i.e.; decisiveness. In spite of that it was found that the grooming of women was not upto the level of men.

Even though women are rated higher in leadership qualities, they still don't outnumber men in positions of leadership (even in America where the Pew survey was conducted). The reasons for this are many and have been explored exhaustively elsewhere. There are, for example, social and systemic barriers limiting women's access to higher office, as well as cultural expectations such as child rearing duties and pregnancy, which conspire against women being hired on equal terms with men. These issues are troubling and must be addressed.

The efficacy of women is natural but one of the problems faced by women in male dominated society is her acceptability as an innovator, for esightness and manager because of that the selfconfidence of women is loosened. The leadership efficacy of women can be enriched by increasing their self-confidence through the development of her entrepreneurial competency which increases the profile of women as a leader. Since, they are assertive, persuasive, empathetic, willing to bear risks, openness, flexible and have a need to get things done in the interest of at large. These personality traits flared-up to create a leadership profile that is more conducive to today's diverse workplace, where dissemination of knowledge and information is 
significant, collaboration is vital and desirable teamwork which distinguishes an organization from others.

The leadership efficacy largely depends upon and can be understood by SWOT analysis of women which differs from individual to individual.

If we start with the SWOT analysis of Women's leadership traits,

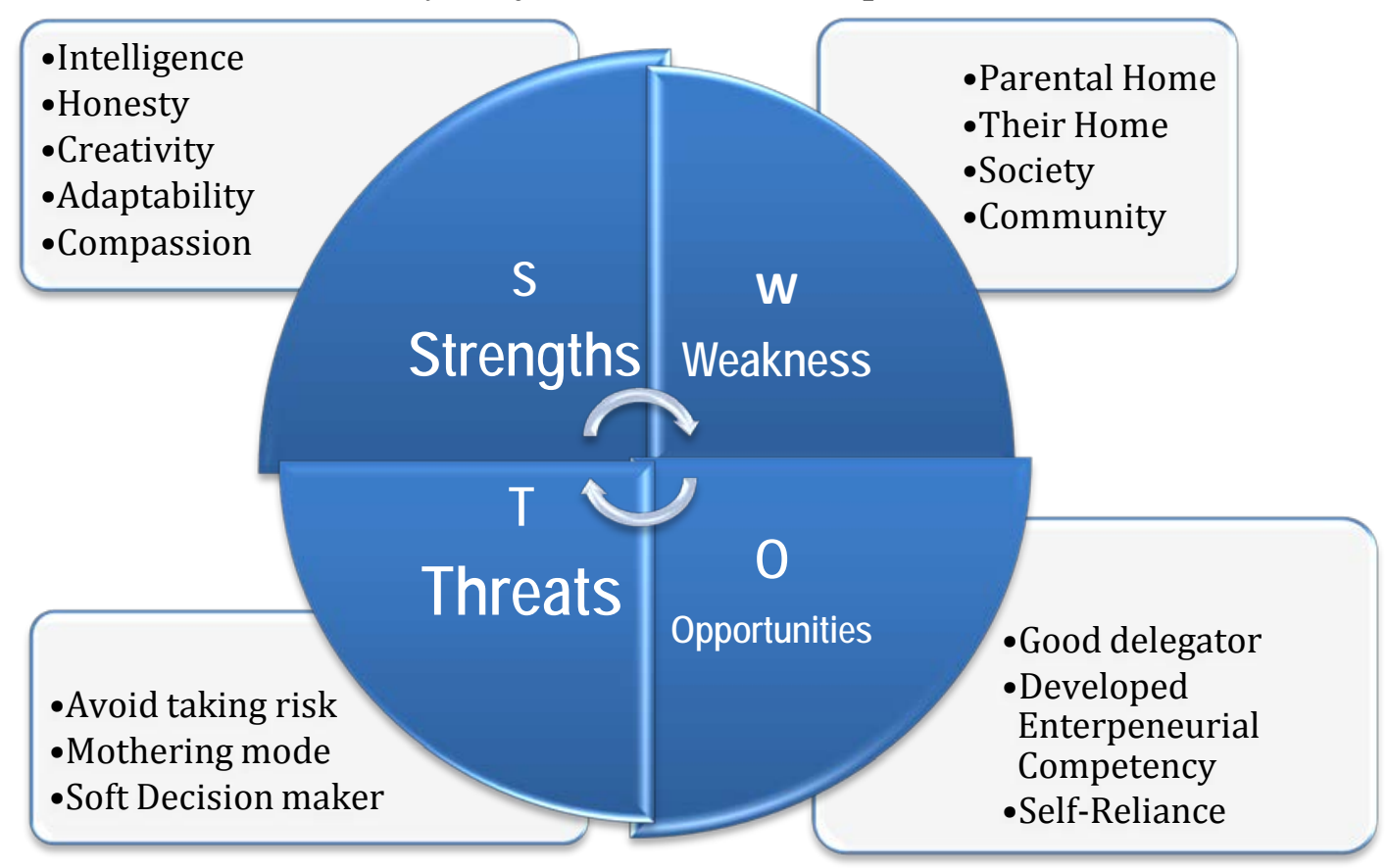

The above analysis reveals a superiority of women traits as compared to men. The following suggestions would makes a women more efficacious. 
Perfect Personality Traits of a Efficacious Woman Leader:

\section{Personality Traits of an Efficacious Women Leader}

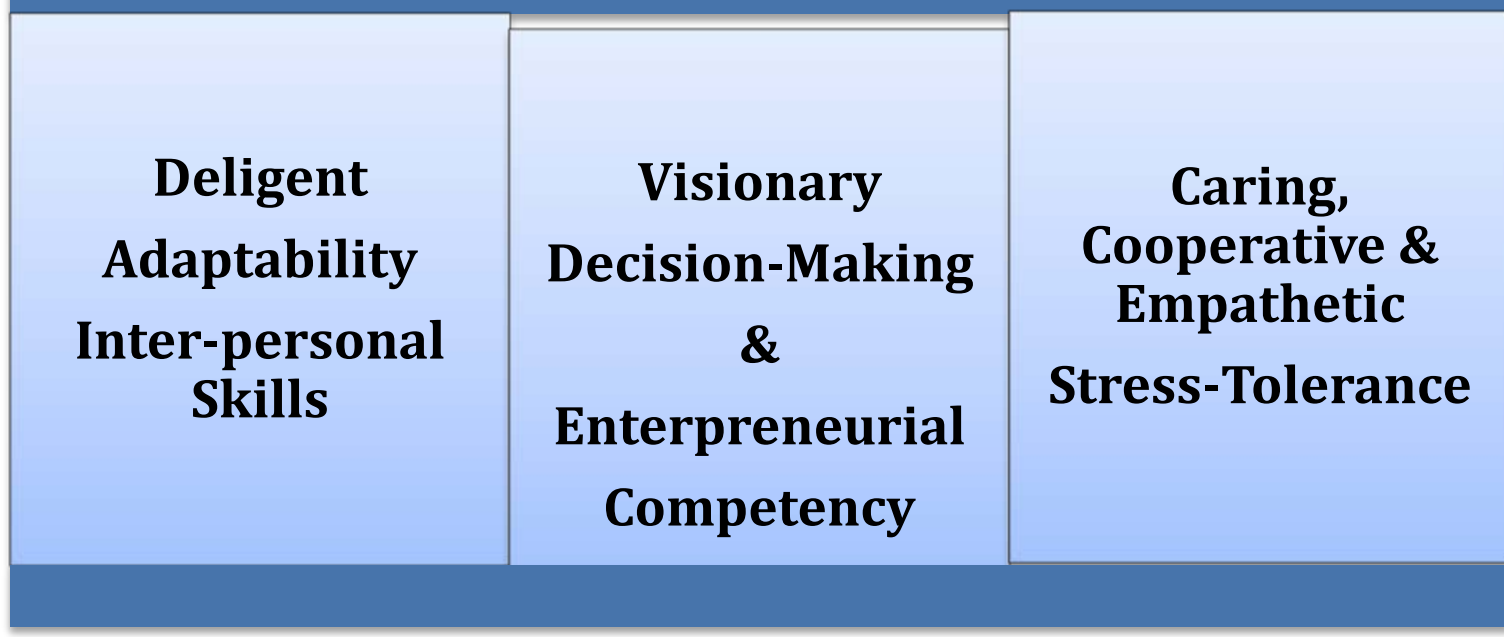

\section{Are women creating a new paradigm of leadership?}

The answer may be "yes."

"So much of what it takes to be a leader has been historically defined by men," explains Libby Sartain of Yahoo! Inc. "And while I was determined to be a leader, the last thing in the world I was going to do was to try to be like a man so that I could be taken seriously. I had to continue to be myself and create a leadership style that worked for me. I'm just not capable of being anyone other than who I am."

This study provides preliminary evidence that women bring distinct personality and motivational strengths to leadership. They have an open, consensus-building, collegial approach to leading.

Jeannette Lichner, Managing Director, Bank of America, says, "The strong leadership profile exhibited by these women on both sides of the Atlantic points to the future. The female view that we strengthen ourselves by strengthening others is redefining leadership." "We're looking at a different paradigm of leadership, and it plays naturally to the strengths of women," says Regina Sacha, Vice President of Human Resources for FedEx Custom Critical. "The tide has turned. The leadership skills that come naturally to women are now absolutely necessary for companies to continue to thrive. It certainly is the reverse of how it was when I first started out in the workplace. It seems like poetic justice.” 


\section{CONCLUSION}

In a male dominant society, men occupy top position as leaders because men are considered as more passionate as compared to women that are why there is a basic irony prevailing in the corporate that women should work harder than men to prove themselves. Women feel constant pressure so as not to make mistake \& prove their value to the organization.

There is a saying that there is a woman behind every successful man. It indicates that women always have an edge over men in respect of positive consultative behavior and providing an environment which is free from stress. If this type of environment is also made available to women, women can also prove his leadership efficacy. But in spite of all odds, women as leaders are contributing at the top and proving their productive leadership skills in shaping the economy which are strongly correlated to organizational success factors such as retaining talent, customer satisfaction, employee engagement, and profitability. Thus, efficacy not only depends upon the personality traits but also conducive and supportive positive environment by the society at large by recognizing at par.

\section{REFERENCES}

Exclusive Sponsor: IBM Corporation; The Double-Bind Dilemma for Women in Leadership

Prof. Indira J Parikh \& Dr. Bharti Kollan.(2003).Women Managers From Myths To Reality.http://www.iimahd.ernet.in/publications/data/2004-03-06indirap.pdf

Roslin Growe\& Paula Montgomery. Women And The Leadership Paradigm: Bridging The Gender Gap.

http://nationalforum.com/Electronic\%20Journal\%20Volumes/Growe,\%20Roslin\%20Wo men\%20and\%20the\%20Leadership\%20Paradigm\%20Bridging\%20the\%20Gender\%20Ga p.pdf.

Herminia Ibarra, Robin J. Ely, Deborah Kolb.(2013).Women Rising: The Unseen Barriers .Harvard Business Publishing

Natalia Karealia \& Laura Guillen. Identity Challenges of Women leaders: Antecedents \& Consequences of Identity Interferences

\section{Webs}

1. http://vaniquotes.org/wiki/Satya-yuga_\%28BG_and_SB\%29

2. http://www.hinduismtoday.com/modules/smartsection/item.php?itemid=5566

3. http://www.buddhistvihara.com/newsletters/2003-winter/status_of_women.htm

4. http://www.dollsofindia.com/library/draupadi/\#.VZYeaET2cVc.email

5. http://www.quora.com/What-are-the-basic-lessons-that-we-can-learn-from-Ramayana

6. http://mandhataglobal.com/wp-content/custom/articles/SocialWomeninHinduism

7. http://wholedude.com/tag/chatur-yugas-kali-yuga/

8. http://www.newworldencyclopedia.org/entry/Yuga

9. http://www.taketheleadwomen.com/wp-content/uploads/2013/03/TTL_LeadershipFictions.pdf

10. https://hbr.org/2012/03/a-study-in-leadership-women-do\&cm_sp=Article-_-Links-_Top\%20of\%20Page\%20Recirculation 